\title{
PENGEMBANGAN MODEL PEMBELAJARAN MOTORIK BERBASIS PERMAINAN
}

\author{
Abdillah \\ Program Studi Penjaskesrek, IKIP PGRI Pontianak \\ Jln. Ampera No. 88 Pontianak \\ e-mail: abdillahabdillah842@gmail.com
}

\begin{abstract}
Abstrak
Penelitian ini bertujuan untuk mengembangan model pembelajaran motorik berbasis permainan dan mengetahui bagaimanakah kelayakan model pembelajaran motorik berbasis permainan pada siswa Sekolah Dasar, Sampel dalam penelitian ini adalah siswa Sekolah Dasar Negeri 08 Sungai Kakap Kabupaten Kubu Raya. Penelitian ini adalah penelitian pengembangan (Research and Development). Sampel dalam penelitian ini adalah seluruh siswa siwa kelas 1 Sekolah Dasar Negeri 08 Kecamatan Sungai Kakap Kabupaten Kubu Raya yang berjumlah 25 siswa. Teknik pengumpul data dalam penelitian ini yaitu teknik komunikasi langsung, dengan instrumen lembar validasi ahli yang digunakan untuk mendapatkan data, lembar validasi ahli dipergunakan untuk melakukan validasi terhadap model pembelajaran motorik berbasis permainan. Berdasarkan validasi ahli terhadap empat model permainan terlihat bahwa hasil yang didapat menunjukan nilai maksimal yai $100 \%$ dengan hasil tersebut dapat disimpulkan bahwa empat model permainan ini sangat baik untuk digunakan dalam pembelajaran motorik.
\end{abstract}

Kata Kunci: Pembelajaran, motorik, berbasis, permainan

\begin{abstract}
This study aims to develop a game-based motor learning model and find out how the feasibility of a game-based motor learning model in elementary school students. The sample in this study is the students of 08 elementary school Sungai Kakap Kubu Raya Regency. This research is a research and development. The sample in this study were all students of grade 1 State Elementary School 08 Sungai Kakap District, Kubu Raya Regency, totaling 25 students. Data collection techniques in this study are direct communication techniques, with an expert validation sheet instrument used to obtain data, an expert validation sheet is used to validate a game-based motor learning model. Based on expert validation of the four game models, it can be seen that the results obtained show a maximum value of $100 \%$ with these results it can be concluded that the four game models are very good for use in motor learning.
\end{abstract}

Keywords: Learning, motor, based, games

\section{PENDAHULUAN}

Pendidikan bagi anak merupakan hal yang sangat penting. Karena melalui pendidikan tersebut dapat membantu perkembangan anak secara optimal. Pemberian pendidikan sejak dini akan mempengaruhi perkembangan otak anak, kesehatan anak, kesiapan anak bersekolah, kehidupan sosial dan ekonomi yang 
lebih baik di masa selanjutnya. Dunia anak adalah dunia bermain,bermain merupakan metode yang tepat bagi guru untuk mengembangkan motorik anak. Saat yang amat menyenangkan bagi anak-anak ketika ia mendapatkan mainan baru. Bagi anak anak, dimana imajinasinya mulai berkembang, benda atau barang apa saja bisa menjadi sarana bermain. Ternyata amat banyak manfaat bermain bagi perkembangan anak-anak terutama, perkembangan pada motorik anak. Memberikan mainan, mengajak bermain atau membuat mainan bersama adalah sebuah upaya untuk membantu perkembangan anak.

Vygotsky (dalam Anita 2011:57), "Bermain merupakan alat pengantar dan kebutuhan pada suatu tahap perkembangan melalui bahasa tulisan akan tumbuh bahasa oral melalui alat (misalnya kendaraan) berupa permainan simbolik". Secara alamiah perkembangan tiap anak berbeda-beda baik dalam bakat, minat, kreativitas, kematangan emosi, kepribadian, keadaan jasmani, dan sosialnya. Dalam usaha mengembangkan kemampuan yang dimiliki anak selalu berdasarkan pada unsur bermain. Bermain sebagai bentuk kegiatan belajar di sekolah haruslah bermain yang kreatif dan menyenangkan sehinggga dapat mengembangkan motorik.

Menurut Woolfolk (2007: 64), "During the preschool years, physical development is fairly steady for most children". Pada masa anak-anak merupakan usia yang paling baik bagi perkembangan fisik anak. Oleh sebab itu, maka pengembangan motorik pada usia ini sangat diutamakan. Selain itu juga sebagai guru yang akan melaksanakan proses pembelajaran yang dapat mengembangkan motorik, kegiatan pengolaan kelas juga sangat berperan penting. Pembelajaran merupakan kegiatan yang mencakup kegiatan belajar mengajar. Pembelajaran bagi anak merupakan proses interaksi anak, orang tua atau orang dewasa lainnya.

Interaksi yang dibangun tersebut merupakan faktor yang mempengaruhi tercapainya tujuan pembelajaran yang akan dicapai. Hal ini disebabkan interaksi tersebut mencerminkan suatu hubungan dimana anak akan memperoleh pengalaman yang bermakna, sehingga proses belajar dapat berlangsung secara lancar. Kegiatan pembelajaran dirancang dengan menggunakan pendekatan tematik. Tema sebagai wadah mengenalkan berbagai konsep untuk mengenal 
dirinya dan lingkungan sekitarnya. Tema yang dipilih dan dikembangkan dari halhal yang paling dekat dengan anak, sederhana, serta menarik minat anak. Apabila tema yang dipilih dan dikembangkan dari hal-hal yang dekat dengan anak, sederhana dan menarik bagi anak maka akan tercipta suasana belajar yang aktif, kreatif, efektif, dan menyenangkan.

Lingkungan pembelajaran harus diciptakan sedemikian menarik dan menyenangkan sehingga anak selalu betah dalam lingkungan sekolah baik di dalam maupun di luar ruangan. Dengan demikian, lingkungan fisik hendaknya memperhatikan keamanan dan kenyamanan anak dalam bermain. Dalam kegiatan pembelajaran pasti mempunyai makna serta tujuan yang hendak dicapai dari kegiatan belajar mengajar. Kegiatan pembelajaran akan dikatakan bermakna apabila, pembelajaran membawa pengaruh perubahan terhadap tingkah laku anak didik dalam mencapai kompetensi dan tujuan yang telah dirumuskan. Menciptakan lingkungan fisik kelas yang kondusif untuk kegiatan pembelajaran anak adalah salah satu tugas pokok guru. Kesungguhan hati dan imajinasi guru kreatif dalam kegiatan pengolaan kelas yang dilakukan guru diharapkan dapat berkreasi berdasarkan atas pemahaman terhadap konsep belajar dan berorientasi pada perkembangan serta karakteristik anak Sekolah dasar.

Pembelajaran motorik halus adalah pembelajaran yang berhubungan dengan keterampilan fisik yang melibatkan otot kecil serta koordinasi antara mata dan tangan". Perkembangan motorik halus setiap anak tentulah tidak sama, baik dari segi kekuatan maupun ketepatan. Kondisi ini dipengaruhi oleh pembawaan dan stimulasi yang diperolehnya. Sebenarnya ada banyak hal yang mempengaruhi perkembangan motorik seorang anak. Tidak hanya suasana dan lingkungan belajar, melainkan juga kondisi lingkungan, dan keluarga, yang turut memberikan pengaruh besar terhadap perkembangan motorik halus anak. Berdasarkan uraian di atas, pembelajaran dilakukan berdasarkan prinsip-prinsip pembelajaran yang mana dalam melakukan prinsip-prinsip pembelajaran tersebut seorang guru atau pendidik harus mengetahui serta memahami setiap kebutuhan serta karakteristik perkembangan setiap anak, sehingga guru atau pendidik nantinya dapat memberikan pembelajaran yang tepat untuk menstimulus setiap aspek 
perkembangan dan meransang munculnya motivasi belajar yang dimiliki oleh anak.

Berdasarkan Standar Kompetensi dan Kompetensi Dasar yang diimplementasikan pada kurikulum Sekolah Dasar dalam standar kompetensi yaitu melakukan gerak dasar dalam permainan sederhana, meliputi: (1) melakukan gerak dasar jalan, lari, dan melompat dalam permainan sederhana; (2) melakukan gerak dasar memutar, mengayun dan menekuk dalam permainan sederhana; (3) melakukan gerak dasar melempar dan menangkap; (4) melakukan sikap tubuh posisi berdiri; (5) melakukan sikap tubuh pada posisi berjalan; (6) melakukan gerak dasar keseimbangan statis tanpa alat; dan (7) mempraktekan gerak berirama dengan musik. Diketahui bahwa dari hasil observasi pelaksanaan pembelajaran penjas di lapangan, guru penjas di sekolah Dasar Negeri 08 Sungai Kakap kurang melakukan variasi-variasi model pembelajaran didalam pelaksanaan proses pembelajaran. Dari hasil observasi tersebut, untuk menghasilkan prestasi belajar anak yang baik maka dibutuhkan suatu model pembelajaran berbasis permainan yang diduga dapat menjadi jalan keluar permasalahan-permasalahan yang ada. Mengingat pentingnya aktivitas motorik untuk melatih keterampilan motorik kasar dan motorik halus anak Sekoalah Dasar. Pendapat dari sebagian besar guru sekolah Dasar Negeri 08 Sungai Kakap memang memerlukan suatu strategi pembelajaran motorik berbasis permainan, sebagian dari mereka mendukung dilakukannya pengembangan model pembelajaran motorik berbasis permainan. Model ini dibuat karena melatih keterampilan motorik anak baik motorik kasar dan motorik halus yang disesuaikan dan dalam porsi yang seimbang. Untuk meningkatkan prestasi belajar yang belum maksimal untuk anak Sekolah Dasar maka perlu dibantu dengan menggunakan model ini. Pada model ini pembelajaran motorik disertakan dengan permainan agar siswa tertarik dan menyenangkan dalam proses belajar serta dapat tercapai tujuan belajar. Oleh karena itu, peneliti ingin mengembangkan model pembelajaran motorik berbasis permainan pada mata pelajaran pendidikan jasmani anak Sekolah Dasar, yang dapat digunakan guru sebagai salah satu bentuk model pembelajaran. Selain itu, model permainan juga berisi materi pelajaran yang terdapat dalam kurikulum, yaitu: (1) materi 
kognitif, (2) materi afektif (sosial, emosional, dan kemandirian), dan (3) materi psikomotorik (fisik/motorik).

\section{METODE}

Penelitian ini merupakan penelitian pengembangan (Research and Development). Metode penelitian dan pengembangan adalah metode penelitian yang digunakan untuk menghasilkan produk tertentu, dan menguji keefektifan produk tersebut (Sugiyono, 2009: 407). Model pengembangan yang digunakan adalah model prosedural yang diadaptasi dari model pengembangan desain instruksional menurut Dick \& Carey dengan langkah-langkah sebagai berikut: (1) melakukan studi pendahuluan dan pengamatan meliputi pengumpulan informasi, dan observasi lapangan, (2) mengembangkan bentuk produk awal, (3) evaluasi produk awal oleh para ahli, (4) melakukan revisi produk pertama dari hasil evaluasi ahli dan uji coba skala kecil, (5) melakukan uji coba skala besar, (6) Revisi produk akhir, dilakukan berdasarkan evaluasi dan analisis uji coba skala besar, dan (7) hasil akhir.

Populasi dalam penelitian ini adalah seluruh siwa Sekolah Dasar Negeri 08 Kecamatan Sungai Kakap Kabupaten Kuburaya, sedangkan sampel dalam penelitian ini adalah seluruh siswa kelas 1 Sekolah Dasar Negeri 08 Kecamatan Sungai Kakap Kabupaten Kuburaya yang berjumlah 25 siswa. Teknik pengumpul data yaitu teknik komunikasi langsung dengan wawancara tidak terstruktur dan teknik dokumentasi. Wawancara tidak terstruktur bersifat lentur dan terbuka, tidak dalam suasana formal, dan bisa dilakukan berulang dengan informan yang sama. Teknik dokumentasi, dalam hal ini dokumen akan digunakan untuk mendapatkan data validasi dari ahli motorik berkaitan dengan pengembangan produk pembelajaran berbasis permainan untuk gerak lokomotor. Alat pengumpul data dalam penelitian ini yaitu menggunakan lembar validasi ahli yang digunakan untuk mendapatkan data, lembar validasi ahli dipergunakan untuk melakukan validasi terhadap model pembelajaran motorik berbasis permainan. 


\section{HASIL DAN PEMBAHASAN}

\section{Hasil}

Tabel 1 menyajikan data hasil pelaksanaan uji coba skala kecil, didapatkan data dari ahli materi dan guru, yang disajikan pada tabel berikut ini.

Tabel 1 Data Ujicoba Skala Kecil

\begin{tabular}{clccccc}
\hline No & Nama Permainan & $\begin{array}{c}\text { Penilaian dari } \\
\text { Guru }(\boldsymbol{\%})\end{array}$ & Kategori & $\begin{array}{c}\text { Penilaian } \\
\text { dari Ahli } \\
(\%)\end{array}$ & Kategori \\
\hline 1 & $\begin{array}{l}\text { Permainan } \\
\text { bola }\end{array}$ & perang & 71 & Baik & 64 & Baik \\
\hline 2 & $\begin{array}{l}\text { Permainan } \\
\text { kancil }\end{array}$ & berburu & 71 & Baik & 78 & Baik \\
\hline 3 & $\begin{array}{l}\text { Permainan } \\
\text { tangkap }\end{array}$ & lempar & 85 & Baik & 78 & Baik \\
\hline 4 & $\begin{array}{l}\text { Permainan } \\
\text { bola }\end{array}$ & sentuh & 78 & Baik & 85 & Baik \\
\hline
\end{tabular}

Proses revisi terhadap draf model permainan yang diuji cobakan pada skala kecil ditindak lanjuti peneliti dengan melakukan uji coba lapangan skala besar di SD Negeri 01 Sengai kakap dan SD N 02 Sungai Kakap. Dari pelaksanaan uji coba skala besar, didapatkan data dari ahli materi (para pakar dan guru SD), meliputi: (1) data hasil observasi permainan, (2) data hasil observasi keefektifan model permainan, (3) data masukan terhadap model permainan. Datadata tersebut disajikan pada tabel 2 .

Tabel 2 Data Ujicoba Skala Besar

\begin{tabular}{clcccc}
\hline No & Nama Permainan & $\begin{array}{c}\text { Penilaian } \\
\text { dari Guru } \\
(\boldsymbol{\%})\end{array}$ & Kategori & $\begin{array}{c}\text { Penilaian } \\
\text { dari Ahli } \\
(\boldsymbol{\%})\end{array}$ & Kategori \\
\hline 1 & Permainan perang bola & 100 & $\begin{array}{c}\text { Sangat } \\
\text { Baik }\end{array}$ & 100 & $\begin{array}{c}\text { Sangat } \\
\text { Baik }\end{array}$ \\
\hline 2 & $\begin{array}{l}\text { Permainan berburu } \\
\text { kancil }\end{array}$ & 100 & $\begin{array}{c}\text { Sangat } \\
\text { Baik }\end{array}$ & 100 & $\begin{array}{c}\text { Sangat } \\
\text { Baik }\end{array}$ \\
\hline 3 & $\begin{array}{l}\text { Permainan lempar } \\
\text { tangkap }\end{array}$ & 100 & $\begin{array}{c}\text { Sangat } \\
\text { Baik }\end{array}$ & 100 & $\begin{array}{c}\text { Sangat } \\
\text { Baik }\end{array}$ \\
\hline 4 & Permainan sentuh bola & 100 & $\begin{array}{c}\text { Sangat } \\
\text { Baik }\end{array}$ & 100 & $\begin{array}{c}\text { Sangat } \\
\text { Baik }\end{array}$ \\
\hline
\end{tabular}


Ahli materi sependapat bahwa model permainan perang bola sangat layak digunakan dalam pembelajaran. Selain itu, para ahli materi sependapat menilai bahwa model permainan sangat baik dalam mentransfer indikator-indikator kejujuran anak dalam bermain.

Pada permainan perang bola secara umum, para ahli materi dan guru SD berpendapat tidak terdapat kekurangan dalam permainan ini, namun terdapat beberapa masukan mengenai pelaksanaan permainan. Pada permainan diberi catatan yaitu ukuran lapangan permainan bisa fleksibel, disesuaikan dengan jumlah anak yang bermain dan kondisi lapangan di sekolah. Melihat masukan tersebut peneliti membuat catatan dalam permainan yang mana permainan ini tidak hanya terbatas pada produk yang dibuat, namun guru dapat memodifikasi permainan ini yang mana di sesuaikan dengan kondisi lapangan di sekolah dan jumlah anak yang mengikuti pembelajaran, apabila guru ingin melibatkan semua anak dalam bermain, lapangan dapat diperbesar sesuai dengan keinginan guru. Masukan yang kedua dari guru SD yaitu bola yang digunakan dapat divariasi dengan menggunakan lebih dari satu bola. Melihat masukan tersebut peneliti menyadari bahwa untuk penggunaan bola dalam permainan ini juga bisa digunakan lebih dari satu buah bola, tergantung dari kondisi siswa yang bermain, apabila guru ingin melibatkan banyak siswa bola yang digunakan bisa lebih dari satu agar mobilitas anak semakin tinggi dalam bermain.

Pada permainan berburu kancil, ahli materi sependapat bahwa model permainan ini baik digunakan dalam pembelajaran. Selain itu, para ahli materi menilai bahwa model permainan sangat baik dalam mentransfer indikatorindikator kejujuran anak dalam bermain. Para ahli materi juga menilai bahwa guru sangat baik dalam menyampaikan model permainan. Secara umum, para ahli materi dan guru SD menilai tidak ada kekurangan dalam permainan ini, namun terdapat beberapa masukan mengenai pelaksanaan permainan. Pertama, ukuran lapangan permainan dapat disesuaikan dengan jumlah anak yang bermain. Berdasarkan masukan tersebut peneliti membuat catatan dalam permainan yang mana permainan ini tidak hanya terbatas pada produk yang dibuat, namun guru dapat memodifikasi permainan ini yang mana di sesuaikan dengan kondisi 
lapangan di sekolah dan jumlah anak yang mengikuti pembelajaran, apabila guru ingin melibatkan semua anak dalam bermain, lapangan diperbesar sesuai dengan keinginan guru. Kedua, masukan dari guru SD bola yang digunakan harus lebih lunak karena menjadi sasaran tembak adalah tubuh siswa. Berdasarkan masukan tersebut maka untuk penggunaan bola dalam permainan ini akan menggunakan bola dengan bahan yang lunak sehingga lebih aman digunakan saat permainan.

Pada permainan lempar tangkap, ahli materi sependapat bahwa model permainan yang dikembangkan layak digunakan dalam pembelajaran. Selain itu, model permainan permainan lempar tangkap sangat baik dalam mentransfer indikator-indikator kerjasama anak dalam bermain. Para ahli materi menilai bahwa guru sebagai pelaksana ujicoba sangat baik dalam menyampaikan model permainan. Secara umum, para ahli materi dan guru SD menilai tidak ada kekurangan dalam permainan ini, namun terdapat beberapa masukan mengenai pelaksanaan permainan yaitu dalam bermain anak tetap aktif dalam bergerak untuk mencari posisi yang kosong pada daerah lawan, jadi anak tidak saja hanya menunggu bola operan dari teman.

Pada permainan sentuh bola ke tubuh lawan, ahli materi sependapat bahwa model permainan sentuh bola ke tubuh lawan layak digunakan dalam pembelajaran. Selain itu, model permainan sangat baik dalam mentransfer indikator-indikator kerjasama anak dalam bermain. Para ahli materi menilai bahwa guru sangat baik dalam menyampaikan model permainan. Secara umum, para ahli materi dan guru SD menilai tidak ada kekurangan dalam permainan ini.

\section{Pembahasan}

Pembelajaran keterampilan motorik di sekolah dasar saat ini sudah menjadi perhatian banyak kalangan, yang menjadi kendala dalam pembelajaran motorik di sekolah dasar adalah masih minimnya pengetahuan guru pendidikan jasmani, olahraga dan kesehatan dalam menerapkan model yang tepat dalam proses belajar mengajar pembelajaran motorik. Hal ini disebabkan oleh kurangnya pengetahuan yang diakibatkan oleh keterbatasan referensi atau sumber bacaan tentang bagaimana guru-guru penjasorkes mengajarkan model pembelajaran 
motorik yang tepat guna mendukung tercapainya hasil pembelajaran. Rusman, (2011: 133) menyatakan bahwa penentuan model pembelajaran yang akan digunakan dalam kegiatan pembelajaran harus mempertimbangkan: (a) tujuan yang hendak dicapai, (b) bahan atau materi pembelajaran, (c) peserta didik, dan (d) pertimbangan lainnya yang bersifat nonteknis. Kemampuan motorik dasar peserta didik juga berpengaruh terhadap proses belajar. Dengan kemampuan motorik dasar tinggi lebih mudah menerima suatu proses pembelajaran dibandingkan dengan peserta didik dengan kemampuan motorik dasar yang rendah. Decaprio, (2013: 24) Melalui pembelajaran motorik di sekolah dasar akan berpengaruh terhadap beberapa aspek kehidupan para siswa seperti: (1) melalui pembelajaran motorik anak mendapat hiburan dan memperoleh kesenangan, (2) melalui pembelajaran motorik anak dapat beranjak dari kondisi lemah menuju kondisi independen, (3) melalui pembelajaran motorik anak dapat menyesuaikan diri dengan lingkungan, (4) melalui pembelajaran motorik akan menunjang keterampilan anak dalam berbagai hal, dan (5) melalui pembelajaran motorik akan mendorong anak bersikap mandiri, sehingga dapat menyelesaikan segala persoalan yang dihadapinya. Selain itu, menurut Riyanto (2016: 17), salah satu bentuk kegiatan dalam pendidikan jasmani yang membuat anak aktif bergerak adalah permainan. Bermain bagi setiap individu merupakan suatu kebutuhan, bermain dapat memenuhi kebutuhan-kebutuhan dan dorongan dalam dirinya (Apriyanto, dkk, 2014).

Berdasarkan hasil penelitian bersumber dari hasil validasi ahli terhadap empat model permainan menunjukan nilai maksimal $100 \%$, dengan hasil tersebut bahwa empat model permainan yang dikembangkan sangat baik untuk digunakan dalam pembelajan motorik. Model-model pembelajaran yang dikembangkan bertujuan untuk membentukan karakter kerjasama, tanggung jawab dan kejujuran untuk siswa SD, yang terdiri dari empat permainan, yaitu: (1) permainan perang bola (2) permainan berburu kancil, (3) permainan lempar tangkap, dan (4) permainan sentuh bola. Hasil penelitian ini memperkuat penelitian Riyanto (2016:20), berdasarkan hasil uji coba produk diketahui bahwa model pembelajaran keterampilan motorik berbasis permainan ini sangat baik untuk 
mengembangkan aspek afektif (sikap), kognitif (pengetahuan) dan psikomotorik (keterampilan) anak sekolah dasar.

\section{SIMPULAN}

Hasil penilaian para ahli dan guru menyatakan bahwa model pembelajaran permainan yang disusun sangat baik dan layak berdasarkan hasil ujicoba dan validasi ahli, dan dapat digunakan dalam pembelajaran motorik. Adapun aktivitas permainan yang dikembangkan terdapatnya unsur jalan, lari, lempar dan lompat. Aspek-aspek tersebut terhimpun dalam beberapa permainan yaitu (1) permainan perang bola, (2) permainan berburu kancil, (3) permainan lempar tangkap, (4) permainan sentuh bola. Produk dari penelitian pengembangan ini yaitu buku panduan model pembelajaran motorik untuk siswa SD, dengan dikembangkannya model permainan ini diharapkan dapat menjadi alternatif bagi guru dalam memberikan pembelajaran gerak lokomotor dengan lebih variatif sekaligus menanamkan nilai-nilai karakter positif khususnya, kerjasama, tanggung jawab dan kejujuran.

\section{DAFTAR PUSTAKA}

Anita, Y. (2011). Model pendidikan anak usia dini. Jakarta: Kencana Prenada Media Group.

Apriyanto, D., Herpratiwi, H., \& Husin, S. (2014). Pengembangan model pembelajaran motorik berbasis permainan. Jurnal Teknologi Informasi Komunikasi Pendidikan (Old), 2(3).

Decaprio, R. (2013). Aplikasi teori pembelajaran motorik di sekolah. Yogyakarta: Diva Press.

Riyanto, I. A, Kristiyanto, A., Purnama, S. K. (2016). Pengembangan model pembelajaran keterampilan berbasis permainan untuk anak sekolah dasar usia 9-10 tahun. Semarang: Universitas Negeri Semarang.

Rusman. (2011). Model-model pembelajaran: mengembangkan profesionalisme guru. Jakarta: Rajawali Pers.

Sugiyono. (2012). Metodoogi penelitian pendidikan pendekatan kuantitatif kualitatif dan $R \& D$. Alfabeta: Bandung.

Woolfolk. (2008). Educational psychology active learning edition tent edition. Boston: Allyn \& Bacon. 